\title{
Geophysical Investigations for Seismic Station of Glogove (Kosovo)
}

\author{
${ }^{1}$ Nazmi Hasi, ${ }^{2}$ Naim Syla and ${ }^{1}$ Arbër Zeqiraj \\ ${ }^{1}$ Department of Materials and Metallurgy, Faculty of Geosciences (FG), University of Mitrovica, \\ PIM-Trepca, KS-40000 Mitrovica, Kosovo \\ ${ }^{2}$ Department of Physics, Faculty of Mathematics and Natural Sciences (FMNS), \\ University of Prishtina, EqremÇabej Str. 51, KS-10000 Prishtina, Kosovo \\ naim.syla@uni-pr.edu
}

\begin{abstract}
During design of a network of seismological stations, it is necessary to fulfill certain conditions that will enable the obtaining of high quality records of seismic waves and defining of earthquake parameters with as better as possible accuracy. This will provide high quality seismological and geophysical data which are of interest for the seismology and the earthquake engineering. The accuracy of the earthquake parameters, the geographical coordinates of the epicenter, the hypocentral depth and the hypocentral time (time at which the earthquake occurred) depend on a number of factors among which are the following: the model of the structure of the Earth's crust in the territory where the stations are installed. This includes: the geometry of the layers, their physical characteristics (velocity of the seismic waves, the density of matter), the homogeneity or the inhomogeneity and alike. The geometrical distribution of the locations of the seismological stations. The geotechnical characteristics of the locations where the seismological stations are installed.
\end{abstract}

Key words: Earthquake, seismic wave, thickness, velocity, geophysical data, homogeneity

\section{INTRODUCTION}

Geophysical investigations are of a particular importance for the behavior of engineering structures and other structures of interest for the society under earthquake effects. This refers not only to the location of the structures themselves but also to their wider surrounding.

The experience from the last earthquake that took place in the surrounding of Gjilan in April 2002 has shown that a network for detailed monitoring of the local seismic activity needs to be installed in Kosovo (Trnkoczy et al., 1998). For that purpose, a proper distribution and selection of sites/locations for installation of the seismological stations will be necessary.

This network of seismological stations will enhance the accuracy of definition of earthquake parameters necessary for the study of the seismicity of the Kosovo territory. The selected locations of seismological stations are compatible and would fit into the seismological networks of the neighboring countries. Anticipated is a real time on-line transfer of data to the main centre, i.e., the Institute of Seismology in Prishtina where the data will be processed.

Their micro locations have been defined based on geological, geophysical and seismological investigations.
Also, the selection of the locations complies with the requirements set by the producer of the seismological and the accessory equipment regarding communication, power supply and physical protection of the structures in which the equipment will be installed.

\section{MATERIALS AND METHODS}

The investigations have been performed by complex application of the following methods (Aki and Richards, 1980). Standard seismic refraction method for measuring velocities of seismic $\mathrm{P}$ and $\mathrm{S}$ waves and definition of the thickness of the surface cover that should be eliminated during foundation of the seismometers of the seismological stations. Seismic reflection method for recording of the local structural-tectonic structure and the boundaries of the subsurface geological media (Scholz, 2005) from which micro seismic vibration and seismic noise could be generated. The seismic investigations have been carried out by using the following set of equipment: the 12-channel seismic digital recording system (TERRACOL MARK-3, ABEM-ATLAS COPCO, Sweden). Vertical and horizontal geophones with natural frequency of 14 and $28 \mathrm{~Hz}$. Hammer with a mass of $10 \mathrm{~kg}$ for signal excitation.

Corresponding Author: Naim Syla, Department of Physics, Faculty of Mathematics and Natural Sciences (FMNS), University of Prishtina, EqremÇabej Str. 51, KS-10000 Prishtina, Kosovo, naim.syla@uni-pr.edu 
The excitation of the seismic waves has been done by hammer blows on a metal plate at each 25 or $60 \mathrm{~m}$ while the signals have been received at each 5 or $10 \mathrm{~m}$ (depending on the presence of surface disintegrated cover or fault zones).

Numerical analysis and interpretation of the measured data has been done by applying the ReflexW set of computer programs (Mihailov et al., 1994).

The investigations have been carried out at individual, normally placed refraction and reflection seismic research profiles. The refraction profiles involved a research depth of $30-40 \mathrm{~m}$. The reflection profiles served for scanning the general geological structure of the location down to a depth exceeding $200 \mathrm{~m}$.

The interpretation of the measured data enabled definition of the values of the seismic $\mathrm{Vp}$ and $\mathrm{Vs}$ velocities in the present geological media and the thickness of the surface quaternary or disintegrated rock layer as well as location of the fault structures that directly affect the selection of the microlocation for the seismological station and the intensity of the seismic noise.

\section{RESULTS AND DISCUSSION}

According to the geological map of the region presented in Fig. 1, the terrain of the seismological station location is composed of serpentine of Jurassic age.

The seismic investigations were performed on a refraction profile with a length of $120 \mathrm{~m}$ (RP-1 in W-E direction) and a reflection profile with a length of $65 \mathrm{~m}$ (RL-1 in N-S direction).

The scheme of the performed profiles and the location of the seismological station is given in Fig. 2. According to the results of the refraction investigations (Fig. 3), there are two elastic media at the site: surface loose layer of serpentine with a depth of 2-3 $\mathrm{m}$ and values of seismic velocities of $\mathrm{Vp}=485$ and $\mathrm{Vs}=320 \mathrm{~m} / \mathrm{sec}$ and compact serpentine below the surface layer with values of seismic velocity of $\mathrm{Vp}=4000$ and $\mathrm{Vs}=2000 \mathrm{~m} / \mathrm{sec}$.

According to the reflection investigations (Fig. 4), the thickness of the serpentines can exceed $300 \mathrm{~m}$. In the surface part, down to the depth of about $120 \mathrm{~m}$, these are cracked and loose. Tectonic changes were recorded in the
Seismic station Llapushnik-Gllogovc

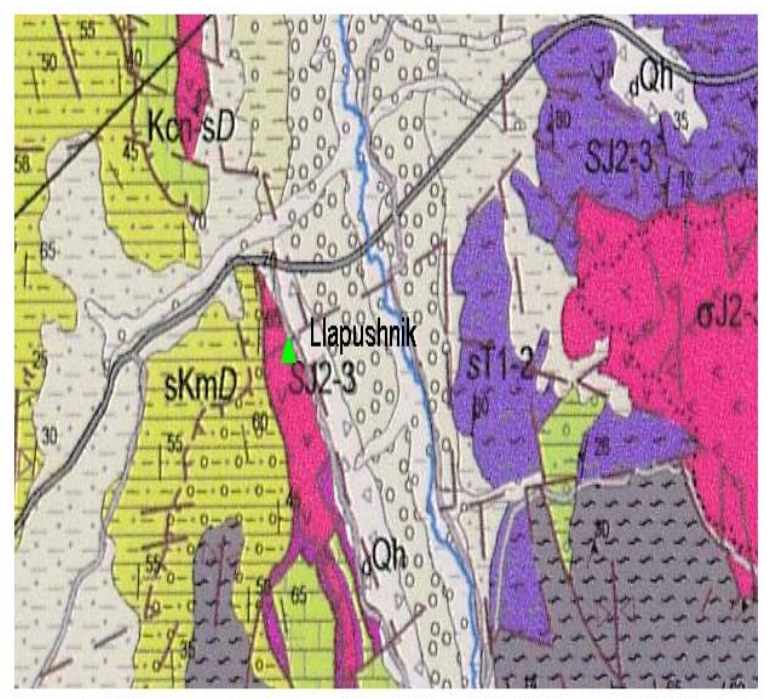

${ }_{\mathrm{d}} \mathrm{Qh}$ Deluvium-rock fragments, sand, silt

tQp River terrces-gravel, sand

IQp Lake sediments-gravel, sand, silt, clay

$\mathrm{Np}^{1}$ Clastic sediments, clay, sand, gravel, marl, carbonate, lenses, burnt rock, lignite

SKDM Sandsone, siltstone, marlstone (flysch)

Kcn-Sd Reef and Rudist limestone $\sim \sim \sim$ sT1-2 Meta-sedimentary silicate rocks-schists, meta-conglomerate

$\beta \mathrm{J} 2-3 \quad$ Basalt

бJ2-3 Peridotite, dunite, partly serpentinised

SJ2-3 Serpentinite

S Station Llapushnik-Gllogovc Coordinates: $42^{\circ} 33^{\prime} 36^{\prime \prime} \mathrm{N}, 20^{\circ} 52^{\prime} 12^{\prime \prime} \mathrm{E}$

Fig. 1: Geological map 


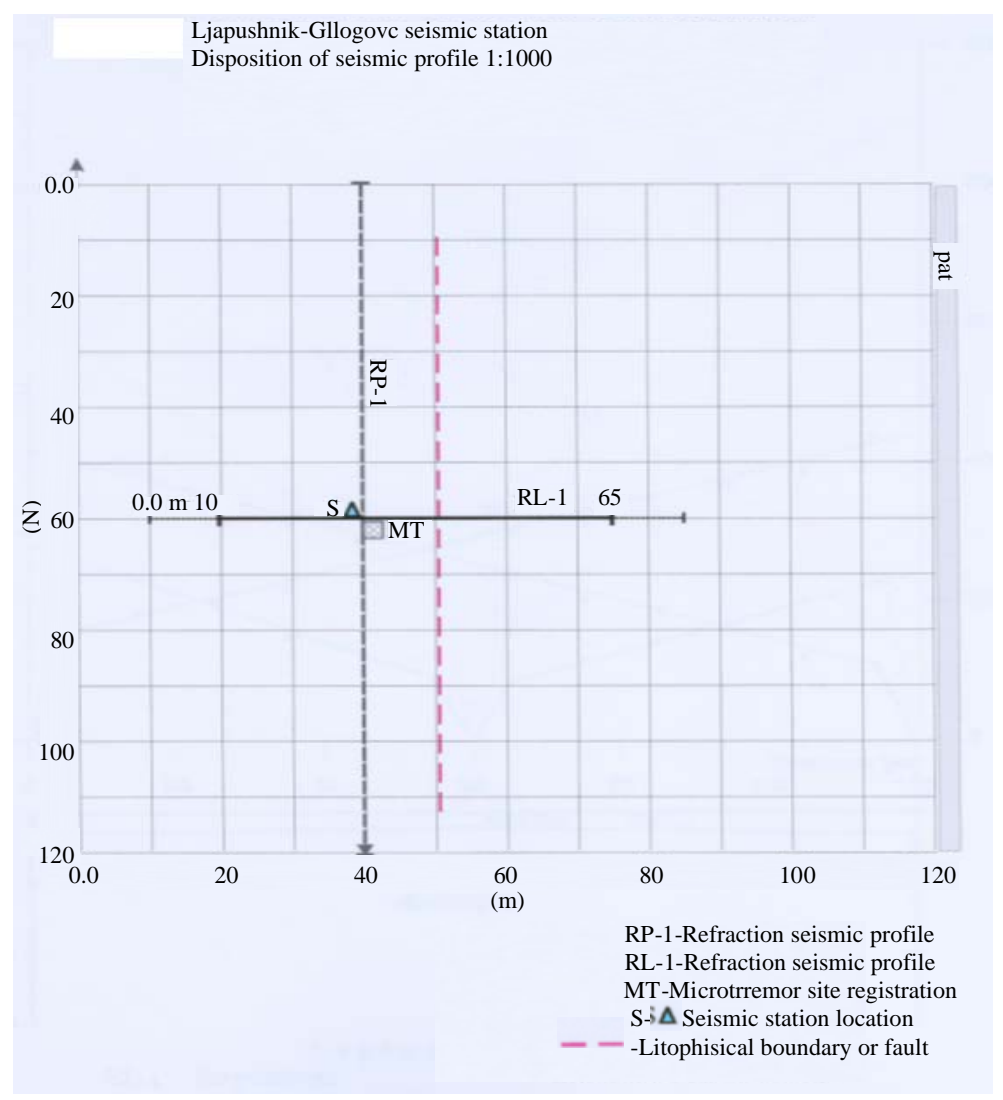

Fig. 2: Llapushnik- Gllogovc seismic station RP-1 (E-W) Seismic reflection profile: a) Time distance curve and b) Velocity model
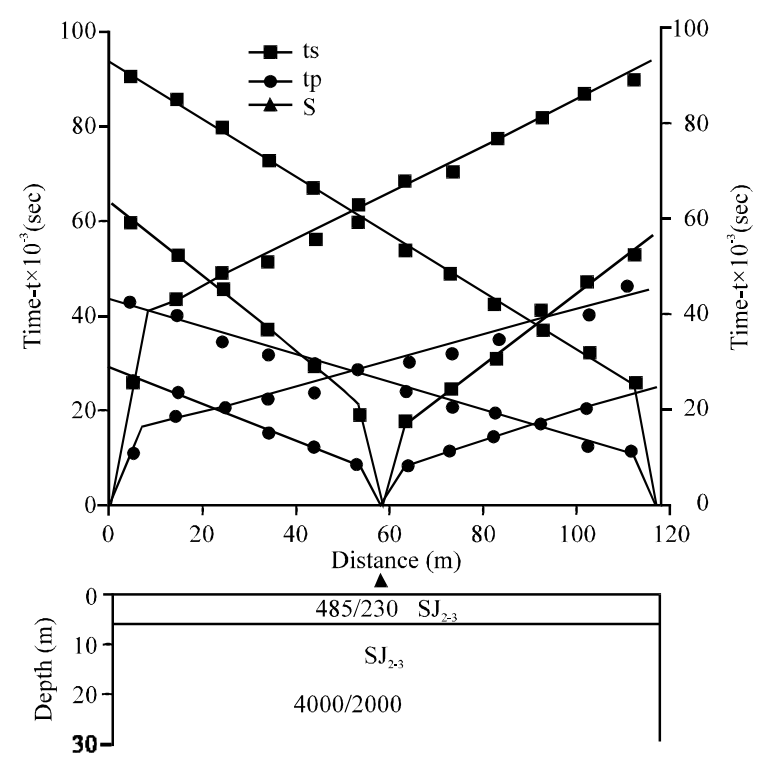

Fig. 3: $\mathrm{SJ}_{2 \cdot 3}$-Serpentiniten weadering layer $\Delta$-S-Seismic statio
$\mathrm{SJ}_{2 \cdot 3}$ Serpentinite surface $4000 / 2000-\mathrm{Vp} / \mathrm{Vs} \quad(\mathrm{m} / \mathrm{sec})$,

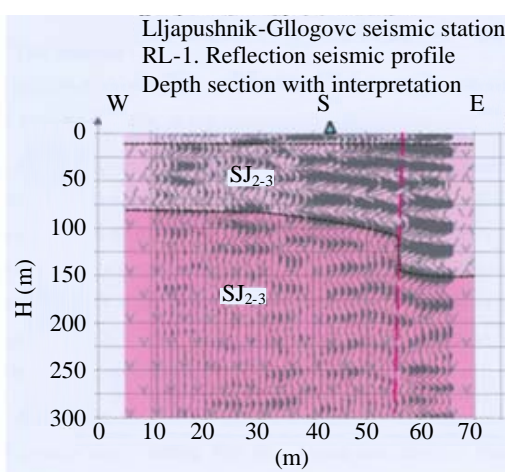

$\mathrm{S}_{\triangle}$ Seismic station location

$$
\begin{array}{lll}
\mathrm{SJ}_{2-3} & \square & \text { Surface serpentinite } \\
\mathrm{SJ}_{2-3} & \text { Undersurface erpentinite } \\
\mathrm{SJ}_{2-3} & \text { Compact erpentinite } \\
\hdashline \ldots \ldots & \text { Litophisical discontinuity } \\
\hdashline- & \text { Fault-litophisical discontinuitv }
\end{array}
$$

Fig. 4: Reflection investigation

East (the lower part of the terrain) part of the reflection profile. According to the values of the seismic velocities, 
the thickness of the loose serpentine and expression $\mathrm{T}=4 \mathrm{~h} / \mathrm{Vs}$, increased micro seismic vibrations with predominant periods of about $0.25 \mathrm{~s}(\mathrm{f}=4 \mathrm{~Hz})$ are expected at this location for seismological station.

\section{CONCLUSION}

The criteria for the selection of the seismic station location Gllogove were the following:

- The geometry of the network

- The seismological conditions and the seismic noise

- The topography (Scholz, 2005)

- The climatic conditions

- The realization resources (the possibility to buy or lease the land, provide electricity and communication, possibilities for construction and access to the site, protection against vandalism)

The selection of the location for seismological station was influenced by the geological conditions in the wider surroundings, distance from larger urban areas, busy roads, railways, etc.

To acquire knowledge about the natural resources at the locations, geological, geophysical and seismological analyses were performed. The goal of this investigations was to install seismological station in Gllogove:

- The seismological station is located on a compact rock surface

- Geophysical seismic refraction and reflection investigations are performed (Havskov and Alguacil, 2004)

- The refraction investigations enabled the definition of

- The values of seismic Vp and Vs velocities of the geological media at the sites down to the depth of about $30-50 \mathrm{~m}$

- The thickness of the surface loose and disintegrated layer to be removed while installing the seismometers of the seismological stations

- The micro locations of the seismological stations on the most compact parts of the refraction profile where the thickness of the surface layer is the lowest, i.e., less than a few meters
The reflection investigations enabled definition of the characteristics of the locations of the seismological stations affecting the amplitude-frequency content of the seismic noise and the earthquake records:

- The geological structure of the terrain of the locations down to the depth of several $100 \mathrm{~m}$

- The local tectonics that can affect the seismic noise at the seismological station

- The micro locations of the seismological stations were defined at places on which no tectonic disturbances were detected

The same network of seismic station can also be equipped with seismological instruments for recording of strong earthquakes for the needs of earthquake engineering and ecological protection of the human environment.

\section{REFERENCES}

Aki, K. and P.G. Richards, 1980. Quantitative Seismology: Theory and Methods. Vol. 1, W.H. Freeman and Company, San Francisko, California, USA., ISBN:9780716710585.

Havskov, J. and G. Alguacil, 2004. Instrumentation in Earthquake Seismology. 2nd Edn., Springer, Dordrecht, TheNetherlands,ISBN:978-3-319-21313-2, Pages: 413.

Mihailov, V., L. Pekevski and D. Mamucevski, 1994. Seismological digital stations network in republic of Macedonia. ISC-World Lab., Erice, Italy.

Scholz, C.H., 2005. The Mechanics of Earthquakes and Faulting. Cambridge University Press, Great Britan, UK.

Trnkoczy, A., P. Bormann, W. Hanka, L.G. Holcomb and R.L. Nigbor, 1998. Site Selection, Preparation and Installation of Seismic Stations. In: New Manual of Seismological Observatory Practice, Bergman, E. and P. Bormann (Eds.). GFZ German Research Centre for Geosciences, Potsdam, Germany, ISBN: 9783980878005, pp: 1-108. 